\title{
Anti-inflammatory and nephroprotective activity of Juglans mollis against renal ischemia-reperfusion damage in a Wistar rat model
}

\author{
Jonathan Perez-Meseguer ${ }^{1}$, Liliana Torres-González¹,2, Jorge Aurelio Gutiérrez-González², Gabriela Alarcón-Galván ${ }^{4}$, \\ Homero Zapata-Chavira ${ }^{3}$, Noemi Waksman-de Torres ${ }^{1}$, Diana Patricia Moreno-Peña², \\ Linda Elsa Muñoz-Espinosa ${ }^{2}$ and Paula Cordero-Pérez ${ }^{2 *}$
}

\begin{abstract}
Background: Oxidative stress and the inflammatory process are involved in ischemia-reperfusion (I/R) injury. Juglans mollis has been reported as having antioxidant activity, which could attenuate the damage caused by I/R. We evaluated whether a methanolic extract of Juglans mollis (JM) exhibits nephroprotective activity in a Wistar rat model of I/R injury.
\end{abstract}

Methods: Four groups of six rats were used: Sham, I/R, JM, and JM + I/R. Two groups were dosed with JM (300 mg/ $\mathrm{kg}$ ) for 7 days before I/R. I/R injury was induced by clamping the renal hilums for $45 \mathrm{~min}$ and then reperfusing the kidneys for $15 \mathrm{~h}$. Blood samples were taken to evaluate the levels of alanine aminotransferase (ALT), blood urea

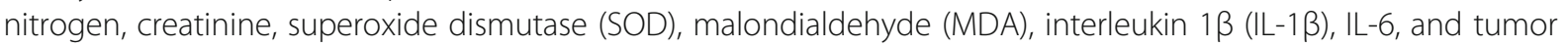
necrosis factor a (TNF-a).

Results: The levels of creatinine, ALT, MDA, IL-1 $\beta, I L-6$, and TNF-a were lower in $J M+I / R$ than in $I / R$ rats, whereas SOD level only was higher in $\mathrm{JM}+\mathrm{I} / \mathrm{R}$ than in Sham rats. No biochemical or histological damage was observed in $J M$ rats compared with Sham rats; however, less histological damage was observed in JM $+1 / R$ rats compared with I/R rats.

Conclusions: To our knowledge, this is the first report of nephroprotective activity of $\mathrm{J}$. mollis against damage induced by I/R. This activity may be related to decreased levels of proinflammatory cytokines (IL-1 $\beta$, IL-6, and TNF-a) and modulation of oxidative stress markers (SOD and MDA) observed in the present study.

Keywords: Juglans mollis, Oxidative stress, Ischemia-reperfusion, Antioxidant

\section{Background}

Renal ischemia-reperfusion (I/R) injury is a major contributor to acute kidney failure. $I / R$ injury results from temporary interruption of blood supply followed by recovery of blood flow, which leads to a profuse oxygenation state in the hypoxic renal tissue $[1,2]$. I/R injury can occur for various reasons, including severe bleeding or when the

\footnotetext{
* Correspondence: paucordero@yahoo.com.mx

2Department of Internal Medicine, Universidad Autónoma de Nuevo León, "Dr. José E. González" University Hospital Liver Unit, Av. Gonzalitos 235, Mitras Centro, C.P. 64460 Monterrey, Nuevo León, Mexico

Full list of author information is available at the end of the article
}

renal blood flow is interrupted for some period, such as during renal transplantation or partial nephrectomy. Regardless of the cause, I/R injury can cause various degrees of damage to kidney tissue [3, 4]. The mechanisms of injury include the production of reactive oxygen species (ROS) and proinflammatory cytokines, and activation of multiple enzymes $[3,5,6]$. Diseases with multiple possible etiologies, such as I/R injury, involve the presence or generation of ROS, and the antioxidant system plays an important role in the course of the disease. For this reason, the use of antioxidant substances as potential agents for

(c) The Author(s). 2019 Open Access This article is distributed under the terms of the Creative Commons Attribution 4.0 International License (http://creativecommons.org/licenses/by/4.0/), which permits unrestricted use, distribution, and 
the treatment of diseases mediated by ROS has attracted worldwide interest $[1,2]$.

Various plants used in traditional medicine have been shown to have antioxidant activity in vitro and in vivo. Some drugs and natural compounds, and crude extracts of certain plants with antioxidant activity, have been evaluated to determine whether they are nephroprotective in rat $\mathrm{I} / \mathrm{R}$ models $[7,8]$. In this context, some species of the Juglans genus exhibit diverse biological activities that may be helpful in the treatment of diseases such as diarrhea, helminthiasis, sinusitis, arthritis, stomach pain, fever, eczema, diabetes mellitus, skin disorders, asthma, hepatitis, liver fibrosis, dysfunctional thyroid, anorexia, urinary tract infection, and cancer [9-13]. The Juglans genus has been reported to have antihypertensive activity [14-17] as well as antioxidant, lipolytic [18], antihyperglycemic, antilipidemic [19], neuronal cellstimulating [20], and antiproliferative properties [21].

Juglans mollis belongs to the family Juglandaceae, commonly known as "nogalillo", "nuez encarcelada", or "nogal blanco", and has been used in traditional medicine in northeastern Mexico for the treatment of infections, skin wounds, and ulcerations. Currently, the evidence for the biological activity of $J$. mollis is inconsistent. It has been reported that an extract of bark from J. mollis has potent antioxidant, hepatoprotective, and antimycobacterial activity [22-24]. In the present study, we evaluated the biological activity of $J$. mollis against renal damage induced by $I / R$ in rats.

\section{Methods}

\section{Plant material}

Bark from J. mollis was collected in Villaldama, N.L., Mexico (26 $23^{\prime} 52.3068^{\prime \prime} \mathrm{N}, 100^{\circ} 25^{\prime} 27.606^{\prime \prime} \mathrm{W}$ ), during summer of 2016. The plant was authenticated by Prof. Humberto Sánchez at the School of Biology of the Universidad Autónoma de Nuevo León and a voucher specimen was deposited in the institutional herbarium (voucher specimen no. UAN-2429). No harm was made to the tree during bark acquisition, since only a small amount was taken. The process did not require the use of roots. According to the institutional guidelines of the UANL, only the approval of a research ethics committee is required for the collection of the plant, since it is only for research purposes (HI17-00002). The bark of J. mollis was ground finely, and $300 \mathrm{~g}$ of the powdered bark was extracted by maceration and shaker agitation with methanol three times for $1 \mathrm{~h}$ each time. The supernatant was filtered and evaporated under reduced pressure at $37^{\circ} \mathrm{C}$, dried in an oxygen-free environment, and stored at $4{ }^{\circ} \mathrm{C}$ until use.

\section{Phytochemical analysis}

The ethanolic extract of $J$. mollis underwent preliminary phytochemical screening to determine the presence of alkaloids (Dragendorff test), carbohydrates (anthrone test), carboxyl groups (sodium bicarbonate test), coumarins (Ehrlich test), flavonoids (Shinoda test), phenolic hydroxyls (ferric chloride test), quinones (Bornträger test), saponins (foam formation test), and sterols and triterpenes (Liebermann-Burchard test) [25].

\section{Animals}

Experiments were performed using male Wistar rats weighing 200-300 g (purchased from Círculo A.D.N., México City). Animals were maintained at a stable room temperature $\left(24 \pm 3^{\circ} \mathrm{C}\right)$ under a 12-h light-dark cycle and fed with commercial rat pellets (Prolab diet 2500, Nutrimix, México City) and water ad libitum. All animal procedures were performed in accordance with the proper use and care of laboratory animals, as approved by the ethics committee of our institution (HI17-00002) and according to the specifications of the Mexican Official Law NOM-062-ZOO-1999.

\section{Experimental design}

To evaluate the activity of $J$. mollis extract in the rat model of renal $I / R$, the following experimental groups were used ( $n=6$ rats/group).

(1) Control (Sham): rats were treated with saline solution for 7 days by oral administration (p.o.), after which they underwent a sham laparotomy without involving the renal pedicle.

(2) J. mollis extract (JM): rats were treated with a 300 $\mathrm{mg} / \mathrm{kg}$ dose of extract for 7 days, after which they underwent a surgical procedure identical to that undergone by the Sham rats.

(3) I/R: rats were treated with saline solution for 7 days, after which acute kidney injury was induced by bilateral ischemia ( $45 \mathrm{~min}$ ) followed by reperfusion $(15 \mathrm{~h})$.

(4) J. mollis extract $+\mathrm{I} / \mathrm{R}(\mathrm{JM}+\mathrm{I} / \mathrm{R})$ : rats were treated with a $300 \mathrm{mg} / \mathrm{kg} /$ day dose of the extract for 7 days (p.o.) continuously before injury, after which, acute kidney injury was induced using the same procedure as that for the I/R group.

\section{Kidney injury}

Rats were anesthetized using xylazine (Sedaject, Vedilab SA de CV, Querétaro, México Reg. SAGARPA Q-0088122) intraperitoneally at a dose of $10 \mathrm{mg} / \mathrm{kg}$ of body weight with ketamine (Anesket, PiSA Agropecuaria SA de CV, Guadalajara, México, Ltd. Reg. SAGARPA Q7833-028) as an analgesic at a dose of $100 \mathrm{mg} / \mathrm{kg}$ according to the specifications of the Mexican Official Law NOM-062-ZOO-1999. The I/R and JM $+I / R$ rats then received a laparotomy. Their kidneys were exposed and then subjected to $45 \mathrm{~min}$ of ischemia by occlusion of the 
renal pedicle, after which the clamps were removed and reperfusion was allowed for $15 \mathrm{~h}$. During this period, the rats were allowed food and water ad libitum. Rats underwent anesthesia and blood samples were collected, all rats were euthanized by exsanguination and serum was stored at $-80^{\circ} \mathrm{C}$ until use. For the Sham and JM rats, the procedure involved laparotomy as for the other groups but without any occlusion. This rat I/R model produces acute kidney damage, as shown by changes in oxidative and inflammatory stress markers, similar to that exhibited by the graft before a transplant in human patients [26].

\section{Biochemical analyses}

Briefly, blood samples were centrifuged for $15 \mathrm{~min}$ at 3, $500 \mathrm{rpm}$ (SIGMA 2-5 Centrifuge, Osterode am Harz, Germany) and the serum was separated. Blood urea nitrogen $(\mathrm{BUN})$, creatinine, and alanine aminotransferase (ALT) concentrations were measured using an ILab-300 Plus clinical chemical analyzer and commercial kits (both from Instrumentation Laboratory, Bedford, MA, USA). The levels of these substances were measured to exclude possible toxic effects of the $J$. mollis extract on the liver and kidney and to assess its effects on renal and hepatic function.

\section{Measurement of malondialdehyde (MDA) concentration}

The extent of lipid peroxidation in renal tissue was estimated by measuring the MDA concentration colorimetrically using a TBARS assay kit (Cayman Chemical Company, Ann Arbor, MI, USA). The absorbance of adducts formed by the reaction of MDA and thiobarbituric acid was measured at $540 \mathrm{~nm}$ on a microplate-reading spectrophotometer (Thermo Scientific Multiskan FC, Waltham, USA) [27]. The results are expressed in terms of MDA equivalents in $\mu \mathrm{mol} / \mathrm{L}$.

\section{Measurement of superoxide dismutase (SOD) activity} SOD activity was measured using a commercial kit (Cayman Chemical Company) following the manufacturer's instructions and is expressed in $\mathrm{IU} / \mathrm{mL}$. Briefly, $200 \mu \mathrm{L}$ of radical detector, $10 \mu \mathrm{L}$ of the tissue homogenate supernatant, and $20 \mu \mathrm{L}$ of xanthine oxidase were added to the reaction mixture and, after $20 \mathrm{~min}$, the absorbance of the mixture was measured at $460 \mathrm{~nm}$ using a microplate-reading spectrophotometer (Thermo Scientific Multiskan FC).

\section{Measurement of serum cytokine concentrations}

The serum concentrations of the inflammatory cytokines interleukin $1 \beta$ (IL-1 $\beta$ ), IL-6, and tumor necrosis factor $\alpha$ (TNF- $\alpha$ ) were measured using a sandwich enzyme-linked immunoassay development kit specific to that cytokine (PeproTech, Mexico City, Mexico). Avidin and avidin-peroxidase were added to produce a colorimetric end product, whose optical density was proportional to the concentration of the cytokine of interest. The optical density was measured at 405 and $620 \mathrm{~nm}$ using a microplate-reading spectrophotometer (Thermo Scientific Multiskan FC). The results are expressed as $\mathrm{ng} / \mathrm{mL}$.

\section{Histological analysis}

Kidneys were resected and fixed in a $10 \%$ formaldehyde solution, embedded in paraffin, and cut into $5-\mu \mathrm{m}$ sections, which were deparaffinized, hydrated, and stained with hematoxylin and eosin. The sections were then evaluated for indicators of cell damage as previously described with some modifications [28-30]. The histopathological changes analyzed were tubular necrosis, proteinaceous casts, exfoliated cells in the lumen, Bowman's space enlargement, lymphocytes in peritubular capillaries, medullary congestion, and intracellular vacuolization.

Tubular necrosis, proteinaceous casts, exfoliated cells in the lumen, Bowman's space enlargement, and lymphocytes in peritubular capillaries were graded as follows: absent (0); mild (1, unicellular, patchy isolated changes or changes in $1-4 \%$ of the observed sample); moderate (2, changes in $5-24 \%$ of the sample); severe ( 3 , changes in $25-50 \%$ of the sample); and very severe (4, changes in $>50 \%$ of the sample).

The degree of medullary congestion was defined as follows: no congestion (0); mild (1, vascular congestion and identification of erythrocytes at $\times 40$ magnification); moderate (2, vascular congestion and identification of erythrocytes at $\times 20$ magnification); severe (3, vascular congestion and identification of erythrocytes at $\times 10$ magnification); and very severe (4, vascular congestion and identification of erythrocytes at $\times 4$ magnification).

The degree of intracellular vacuolization or tubular epithelial edema was defined as follows: absent (0), focal cellular edema (1), mild diffuse cellular edema (2), moderate diffuse cellular edema (3), and severe diffuse cellular edema (4).

Table 1 Phytochemical analysis of Juglans mollis

\begin{tabular}{lc}
\hline Chemical type & J. mollis \\
\hline Alkaloids & + \\
Carbohidrates & + \\
Carboxyl group & - \\
Coumarines & + \\
Flavonoids & + \\
Phenolics & + \\
Saponins & - \\
Sterols and triterpens & + \\
Quinones & + \\
\hline
\end{tabular}

+ , positive; -, negative 


\section{Statistical analysis}

All data are expressed as the mean \pm standard deviation of the mean. The data were analyzed using one-way analysis of variance with the Tukey post hoc test for parametric data or the Kruskal-Wallis test with a Dunn post hoc test for nonparametric data. Prism software (version 6.0; GraphPad, San Diego, CA, USA) was used for the analyses. Differences between means were considered significant at $p<0.05$.

\section{Results}

\section{Phytochemical profile}

The phytochemical profile of J. mollis is shown in Table 1. All the functional tests were positive except for carboxyl groups and saponins.

\section{Biochemical markers}

Serum BUN concentration was higher in $\mathrm{I} / \mathrm{R}$ rats than in Sham rats $(83.00 \pm 10.00 \mathrm{mg} / \mathrm{dL}$ vs. $12.00 \pm 2.00 \mathrm{mg} / \mathrm{dL}$, respectively) but did not differ between JM (15.00 \pm 3.00 $\mathrm{mg} / \mathrm{dL}$ ) and Sham rats. Serum BUN concentration was lower in $\mathrm{JM}+\mathrm{I} / \mathrm{R}$ rats than in $\mathrm{I} / \mathrm{R}$ rats, but the difference was not significant $(62.00 \pm 26.00 \mathrm{mg} / \mathrm{dL}$ vs. $83.00 \pm$ $10.00 \mathrm{mg} / \mathrm{dL}$ ) (Fig. 1 a). Creatinine concentration was normal and did not differ between Sham and JM rats $(0.53 \pm 0.07 \mathrm{mg} / \mathrm{dL}$ vs. $0.42 \pm 0.03 \mathrm{mg} / \mathrm{dL}$, respectively) Creatinine concentration was significantly higher in $I / R$ rats $(2.66 \pm 0.48 \mathrm{mg} / \mathrm{dL})$ than in Sham, JM, and JM + I/R rats $(1.28 \pm 0.42 \mathrm{mg} / \mathrm{dL})$ (Fig. $1 \mathrm{~b})$. Serum ALT concentration, an indicator of liver damage, did not differ between Sham, I/R, and JM rats $(89.00 \pm 6.00 \mathrm{IU} / \mathrm{L}$, $86.00 \pm 3.00 \mathrm{IU} / \mathrm{L}$, and $78.00 \pm 9.00 \mathrm{IU} / \mathrm{L}$, respectively); however, serum ALT concentration was significantly lower in $J M+I R$ rats $(66.00 \pm 9.00 \mathrm{IU} / \mathrm{L})$ than in $\mathrm{I} / \mathrm{R}$ or Sham rats (Fig. $1 \mathrm{c}$ ).

\section{Oxidative stress markers}

Tissue MDA concentrations were significantly higher in $\mathrm{I} / \mathrm{R}$ rats $(1405.00 \pm 151.00 \mathrm{mM})$ than in Sham rats $(263.00 \pm 64.00 \mathrm{mM}), \mathrm{JM}$ rats $(742.00 \pm 46.00 \mathrm{mM}$, and $\mathrm{JM}+\mathrm{I} / \mathrm{R}$ rats $(816.00 \pm 75.00 \mathrm{mM})$. However, MDA concentration did not differ significantly between $J M+I / R$ and $J M$ rats (Fig. $1 \mathrm{~d}$ ).

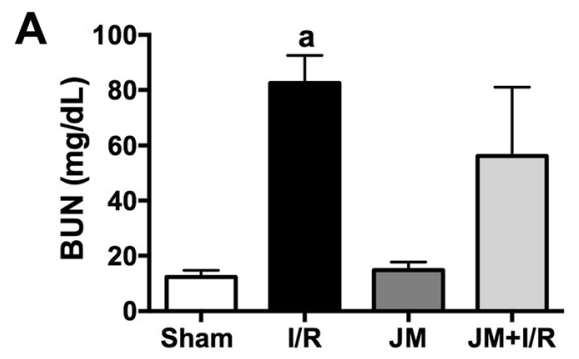

B
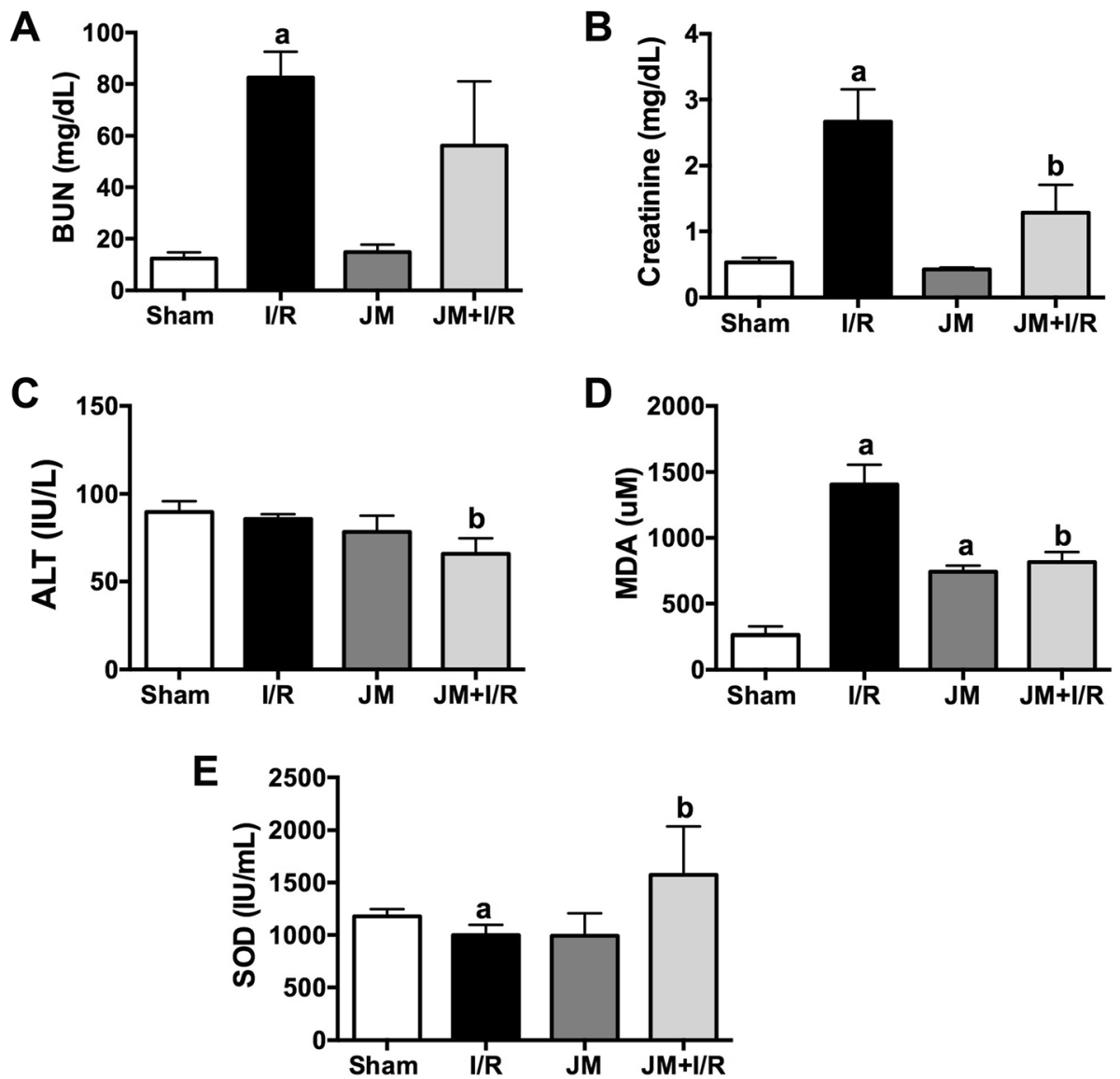

Fig. 1 Changes in (a) BUN (b) Creatinine, (c) ALT, (d) MDA, and (e) SOD levels after I/R injury. Values are mean \pm SD. a. $p<0.05$ comparison with the sham group; b. $p<0.05$, comparison with IR group 
SOD concentration was significantly lower in $I / R$ rats than in Sham rats $(998.00 \pm 98.00 \mathrm{IU} / \mathrm{mL}$ vs. $1178.00 \pm$ $67.00 \mathrm{IU} / \mathrm{mL}$, respectively), but not compared with JM rats $(992.00 \pm 216.00 \mathrm{IU} / \mathrm{mL})$. Interestingly, SOD concentration was significantly higher in JM + I/R rats $(1573.00 \pm 463.00$ $\mathrm{IU} / \mathrm{mL}$ ) than in Sham rats (Fig. 1e).

\section{Serum cytokines}

The concentrations of the three cytokines tested (IL-1 $\beta$, IL- 6 , and TNF- $\alpha)$ were higher in I/R rats $(1.36 \pm 0.08 \mathrm{ng} /$ $\mathrm{mL}, 0.39 \pm 0.05 \mathrm{ng} / \mathrm{mL}$, and $0.70 \pm 0.04 \mathrm{ng} / \mathrm{mL}$, respectively) than in Sham rats $(0.86 \pm 0.12 \mathrm{ng} / \mathrm{mL}, 0.14 \pm 0.02$ $\mathrm{ng} / \mathrm{mL}$, and $0.40 \pm 0.07 \mathrm{ng} / \mathrm{mL}$, respectively). Only IL-6 concentration was higher in JM rats $(0.23 \pm 0.01 \mathrm{ng} / \mathrm{mL})$ than in Sham rats. The concentrations of the three proinflammatory cytokines were significantly lower in JM + $\mathrm{I} / \mathrm{R}$ rats $(0.66 \pm 0.08 \mathrm{ng} / \mathrm{mL}, \quad 0.25 \pm 0.02 \mathrm{ng} / \mathrm{mL}$, and $0.26 \pm 0.07 \mathrm{ng} / \mathrm{mL}$, respectively) than in $\mathrm{I} / \mathrm{R}$ rats (Fig. 2).

\section{Histology}

Kidneys from the Sham rats showed tubules, glomeruli, and a generally preserved structure. I/R kidneys exhibited dilatation and tubular necrosis in a generalized diffuse band in the medulla. In I/R kidneys, the cortex was preserved only in the lower part, protein cylinders were seen in the tubular lumen, and generalized diffuse necrosis was apparent. The JM kidneys also showed a preserved cortex, medulla, and general structure, and had an imperceptible inflammatory infiltrate. In the JM $+\mathrm{I} / \mathrm{R}$ kidneys, injury was seen only in certain sections of the medulla, tubular dilatation and necrosis appeared focally, and ghost cells were observed between apparently preserved cells (Fig. 3). The histological parameters evaluated are shown in Table 2. The extent of tubular necrosis, medullary congestion, proteinaceous casts, and Bowman's space enlargement differed significantly between IR and JM + IR rats.

\section{Discussion}

During the I/R process, ROS accumulate, and this accumulation of ROS can lead to cell dysfunction and even cell death [31]. Various enzymes with antioxidant activity, such as SOD, participate in the neutralization of ROS [32]. However, under oxidative stress, the imbalance between the production of ROS and the ability of enzymes to counteract these oxidative radicals can lead to significant tissue damage and may be irreversible [24]. Many plants are recognized as a source of nonenzymatic antioxidants capable of attenuating oxidative damage induced by ROS [33].

Several species of the Juglans genus, such as J. regia, J. mandshurica, and J. microcarpa, have been shown to have substantial antioxidant activity in both in vivo and in vitro models $[9,13,18]$. Some polyphenols isolated

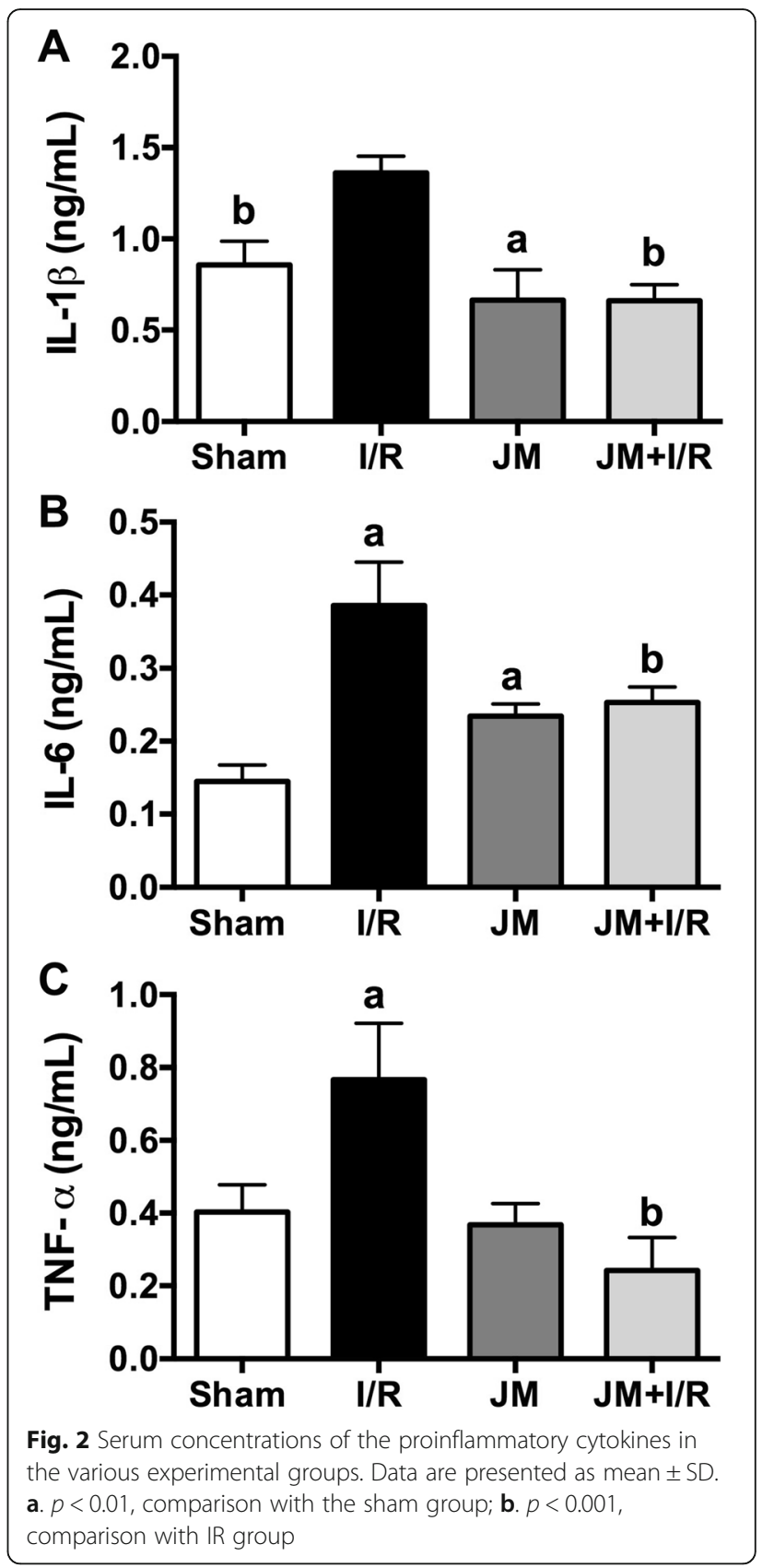

from these species have been shown to have hepatoprotective and nephroprotective effects by increasing the activities of SOD and catalase [34, 35], which may mediate the plants' antioxidant activities.

In this study, we assessed whether a methanolic extract of $J$. mollis has nephroprotective effects. We found that the oxidative stress damage induced by $\mathrm{I} / \mathrm{R}$ process in $J M+I / R$ rats was attenuated when the SOD concentration was increased. Previous studies by our group have identified an important antioxidant activity of $J$. mollis $[22,24]$ that may be involved in protecting against $\mathrm{I} / \mathrm{R}$ damage. By contrast, the concentration of MDA, 

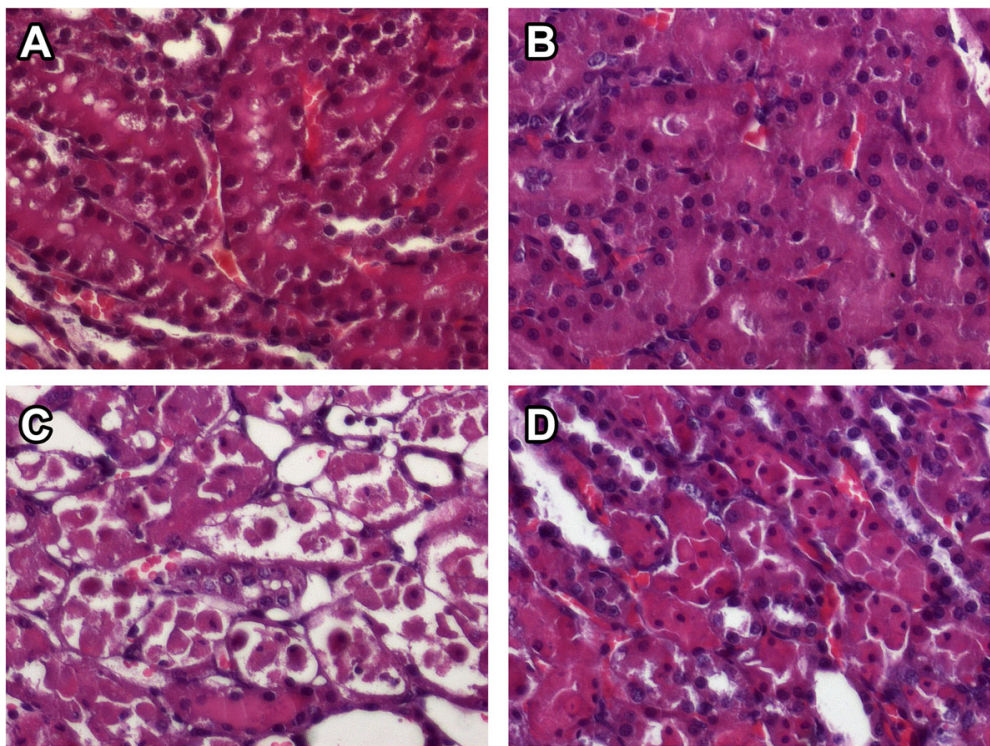

Fig. 3 Histological sections of renal tissue $\times 40(\mathrm{H \& E})$. Sham (a), JM (b), I/R (c), and JM+l/R (d)

another marker of oxidative stress whose tissue levels increase in association with tissue damage, was lower in $J M+I / R$ rats. This observation is consistent with the findings of a study about the effects of another species of Juglans ( $\mathrm{J}$. mandshurica) on the inhibition of peroxidation of lipids, which reported increased SOD and glutathione peroxidase levels, and decreased MDA level [36]. By contrast, MDA concentration was slightly higher in JM rats than in Sham rats. Various compounds such as anthocyanins (present in other species of Juglans) are interfering compounds that absorb at $532-540 \mathrm{~nm}$. This may contribute to an overestimation of the MDA concentration, which may explain the higher concentration of this mediator of oxidative stress in the JM group [37-39].

In the present study, J. mollis extract exhibited functional groups that are characteristic of antioxidant compounds such as coumarins, flavonoids, phenolics, quinones, and carbohydrates (commonly linked to flavonoids). Terpenes and alkaloids were also present. These polyphenolic compounds may be responsible for the nephroprotective and antioxidant activities found here and the hepatoprotective effects reported previously [22, 24].
No toxicity has been reported for extracts obtained from the genus Juglans at the doses evaluated in a biological study [40]. We also found that $J$. mollis extract at the doses tested did not increase the concentrations of markers of hepatotoxicity (ALT and AST) and nephrotoxicity (BUN and creatinine), as shown by the lack of difference between these levels in JM and Sham rats.

Th1-type $\mathrm{CD}^{+}{ }^{+} \mathrm{T}$ lymphocytes secrete proinflammatory cytokines such as TNF- $\alpha$, IFN- $\gamma$, IL-2, and IL-12, whereas Th2-type $\mathrm{CD} 4^{+} \mathrm{T}$ lymphocytes secrete anti-inflammatory cytokines such as IL-4, IL-5, IL-10, and IL13. Th2 cells exhibit seem to protect against I/R damage, whereas Th1 cells have deleterious effects [41-43], which suggests that an imbalance between the activities of these cell types can influence the extent of I/R lesions in the kidney during the transplantation process. For example, a large increase in the production of proinflammatory markers such as IL-1 $\beta$, IL-6, and monocyte chemotactic protein 1 has been observed during recovery immediately after kidney transplantation [44].

Immunostimulating agents can be isolated from plants of the Juglans genus (J. major [45] and J. jamaicensis [46]). Compounds with immunostimulatory activity,

Table 2 Histopathological changes in all studied groups

\begin{tabular}{llllllll}
\hline $\begin{array}{l}\text { Experimental } \\
\text { group }\end{array}$ & $\begin{array}{l}\text { Intracellular } \\
\text { vacualization }\end{array}$ & $\begin{array}{l}\text { Medullary } \\
\text { congestion }\end{array}$ & $\begin{array}{l}\text { Proteinaceous } \\
\text { casts }\end{array}$ & $\begin{array}{l}\text { Exfoliated cells in } \\
\text { the lumen }\end{array}$ & $\begin{array}{l}\text { Tubular } \\
\text { necrosis }\end{array}$ & $\begin{array}{l}\text { Lymphocytes in } \\
\text { peritubular capillares }\end{array}$ & $\begin{array}{l}\text { Bowman's space } \\
\text { enlargement }\end{array}$ \\
\hline Sham & $1.17 \pm 0.41$ & $0.17 \pm 0.41$ & $0.67 \pm 0.82$ & $0.17 \pm 0.41$ & $0.00 \pm 0.00$ & $0.67 \pm 0.52$ & $0.33 \pm 0.52$ \\
I/R & $2.20 \pm 0.45^{\mathrm{a}}$ & $3.83 \pm 0.41^{\mathrm{a}}$ & $3.60 \pm 0.55^{\mathrm{a}}$ & $4.00 \pm 0.00^{\mathrm{a}}$ & $4.00 \pm 0.00^{\mathrm{a}}$ & $1.00 \pm 0.00$ & $2.80 \pm 0.45^{\mathrm{a}}$ \\
$\mathrm{JM}$ & $1.00 \pm 0.00$ & $1.00 \pm 0.71$ & $0.20 \pm 0.45$ & $0.40 \pm 0.55$ & $0.00 \pm 0.00$ & $1.00 \pm 0.00$ & $0.40 \pm 0.55$ \\
$\mathrm{JM}+\mathrm{I} / \mathrm{R}$ & $2.00 \pm 0.00$ & $0.50 \pm .83^{\mathrm{b}}$ & $2.00 \pm 0.71^{\mathrm{b}}$ & $2.80 \pm 0.45^{\mathrm{b}}$ & $2.00 \pm 0.00^{\mathrm{b}}$ & $1.00 \pm 0.00$ & $0.60 \pm 0.89^{\mathrm{b}}$ \\
\hline
\end{tabular}

Values represent the mean \pm S.D. $(n=6)$ of histopathological grade. Grade: no change (0), mild (1), moderate (2), severe (3), very severe (4). a. $p<0.05$, comparison with the sham group; b. $p<0.05$, comparison with IR group 
such as the polysaccharide JRP1, which has an immunostimulatory effect in vivo by increasing the release of IFN- $\gamma$ and IL-2, have been isolated from other species, including $J$. mandshurica $[47,48]$. J. regia has been reported to have anti-inflammatory [49], antibacterial [50, $51]$, and antidiabetic $[52,53]$ properties. An extract of $J$. regia can inhibit nuclear factor $\mathrm{\kappa B}(\mathrm{NF}-\mathrm{kB})$ induced by TNF- $\alpha$ [54] and is an astringent because of its tannin content [55]. In the present study, I/R rats had high serum concentrations of the three proinflammatory cytokines IL-1 $\beta$, IL- 6 , and TNF- $\alpha$, whereas the JM $+\mathrm{I} / \mathrm{R}$ rats had significantly lower concentrations of these three cytokines compared with the I/R rats. The concentrations of IL- $1 \beta$ and TNF- $\alpha$ were similar in JM and Sham rats, but IL-6 concentration was significantly higher in JM than in Sham rats. Similar effects have been reported for mononuclear cells from healthy people treated with a diet of olive oil and nuts, who showed a reduction in the postprandial response of proinflammatory cytokines with the exception of IL-6 [56].

Generalized damage along with tubular necrosis was observed as the formation of proteinaceous casts in the cortex and medulla in rat kidneys subjected to I/R injury. More structures were preserved and more focal tubular necrosis was observed at certain points in the medulla in $\mathrm{JM}+\mathrm{I} / \mathrm{R}$ rat kidneys. Kidneys from Sham and JM rats did not show any damage. In this study, several structural changes were observed in the renal tissue of JM $+I / R$ rats, including decreasing tubular necrosis, medullary congestion, proteinaceous casts, and Bowman's space enlargement, which is consistent with our results of biochemical, inflammatory and oxidative stress markers. These findings suggest that, at the histological level, J. mollis extract had a nephroprotective effect in rats subjected to I/R injury.

\section{Conclusions}

To our knowledge, this is the first report of the nephroprotective activity of $J$. mollis against renal damage induced by I/R. This effect may be related to decreased production of proinflammatory cytokines (IL-1 $\beta$, IL-6, and TNF- $\alpha$ ) and modulation of oxidative stress markers (SOD and MDA) observed in the present study. The substantial antioxidant activity reported previously for this plant species may also be involved. Bioguided assays are needed to identify the compounds responsible for the activity of the methanolic extract of $J$. mollis.

\footnotetext{
Abbreviations

${ }^{\circ} \mathrm{C}$ : celsius degrees; ALT: Alanine aminotransferase; BUN: Blood urea nitrogen; dL: deciliter; g: grams; h: hours; h: hours; H\&E: hematoxylin and eosin; I/ R: Ischemia/reperfusion; IL: Interleukin; IU: International unit; JM: Juglans mollis extract; kg: kilograms; MDA: malondialdehyde; mg: milligrams; min: minutes; mM: millimoles; ng: nanograms; nm: nanometers; p.o.: oral administration; ROS: Reactive oxygen species; SOD: Superoxide dismutase; TNF: Tumor necrosis factor; U/L: Units per liter; uL: microliters; um: micrometer
}

\section{Acknowledgements}

The authors gratefully acknowledge CONACYT México for support through Red Farmoquímicos (CONACYT No 294727).

\section{Authors' contributions}

PMJ designed the study, acquired, analyzed, and interpreted the data, wrote the article, made critical revisions, and gave final approval of the version to be published; TGL designed the study, acquired, analyzed and interpreted the data, wrote the article, made critical revisions and gave final approval of the version to be published; GGJA acquired, analyzed and interpreted the data, wrote the article and made critical revisions; GAG analyzed and interpreted the data, drafted the article and made critical revisions; $\mathrm{ZCH}$ analyzed and interpreted the data, drafted the article and made critical revisions; WTN analyzed and interpreted the data, drafted the article and made critical revisions; MPDP designed the study, acquired, analyzed, interpreted the data, wrote the article, made critical revisions and gave final approval of the version to be published; MELE analyzed and interpreted the data, drafted the article, and made critical revisions; PRE analyzed and interpreted the data, drafted the article, and made critical revisions; CPP conceptualized and designed the study, acquired, analyzed, and interpreted the data, wrote the article, made critical revisions, and gave final approval of the version to be published.

\section{Funding}

Collection, analysis and writing of this project were financially supported by resources of the Liver Unit.

\section{Availability of data and materials}

The datasets supporting the conclusions of this article are included within the article.

\section{Ethics approval}

All animal procedures were performed in accordance with the proper use and care of laboratory animals, as approved by the ethics committee of our institution (HI17-00002) and according to the specifications of the Mexican Official Law NOM-062-ZOO-1999.

\section{Consent for publication}

Not applicable in this section.

\section{Competing interests}

The authors declare that they have no competing interest.

\section{Author details}

${ }^{1}$ Department of Analytical Chemistry, Universidad Autónoma de Nuevo León School of Medicine, Av Dr. Aguirre Pequeño and Madero S/N, Mitras Centro, C.P 64460 Monterrey, Nuevo León, Mexico. ²Department of Internal Medicine, Universidad Autónoma de Nuevo León, "Dr. José E. González" University Hospital Liver Unit, Av. Gonzalitos 235, Mitras Centro, C.P. 64460 Monterrey, Nuevo León, Mexico. ${ }^{3}$ Universidad Autónoma de Nuevo León, "Dr. José E. González" University Hospital Transplant Service, Av. Gonzalitos 235, Mitras Centro, C.P. 64460 Monterrey, Nuevo León, Mexico. ${ }^{4}$ Basic Science Department, Universidad de Monterrey, School of Medicine, UDEM, Av. Ignacio Morones Prieto 4500, C.P 66238 San Pedro Garza García, Nuevo León, Mexico.

Received: 30 October 2018 Accepted: 19 July 2019

Published online: 26 July 2019

\section{References}

1. Zahran MH, Hussein AM, Barakat N, Awadalla A, Khater S, Harraz A, et al. Sildenafil activates antioxidant and antiapoptotic genes and inhibits proinflammatory cytokine genes in a rat model of renal ischemia/ reperfusion injury. Int Urol Nephrol. 2015;47:1907-15.

2. Basile DP, Anderson MD, Sutton TA. Pathophysiology of acute kidney injury. Compr Physiol. 2012;2:1303-53

3. Montagna G, Hofer CG, Torres AM. Impairment of cellular redox status and membrane protein activities in kidneys from rats with ischemic acute renal failure. Biochim Biophys Acta. 1998;1407:99-108.

4. Hussein AA, Shokeir AA, Sarhan ME, El-Menabawy FR, Abd-Elmoneim HA, ElNashar EM, et al. Effects of combined erythropoietin and epidermal growth 
factor on renal ischaemia/reperfusion injury: a randomized experimental controlled study. BJU Int. 2011 Jan;107(2):323-8.

5. Devarajan P. Update on mechanisms of ischemic acute kidney injury. J Am Soc Nephrol. 2006;17:1503-20.

6. McCord JM. Oxygen-derived free radicals in postischemic tissue injury. N Engl J Med. 1985;312:159-63.

7. Cho EJ, Yokozawa T, Rhee SH, Park KY. The role of Coptidis Rhizoma extract in a renal ischemia-reperfusion model. Phytomedicine. 2004;11:576-84.

8. Hosseinzadeh H, Sadeghnia HR, Ziaee T, Danaee A. Protective effect of aqueous extract saffron (Crocus sativus L.) and crocin, its active constituent, on renal ischemia-reperfusion injury-induced oxidative damage in rats. J Pharm Sci. 2005;8:387-93.

9. Panth N, Paudel KR, Karki R. Phytochemical profile and biological activity of Juglans regia. J Integr Med. 2016;14:359-73.

10. Erdemoglu N, Küpeli E, Yeşilada E. Anti-inflammatory and antinociceptive activity assessment of plants used as remedy in Turkish folk medicine. J Ethnopharmacol. 2003;89:123-9.

11. Taha NA, Al-wadaan MA. Utility and importance of walnut, Juglans regia Linn: a review. Afr J Microbiol Res. 2011;5:5796-805.

12. Jaradat NA, Zaid AN, Al-Ramahi R, Alqub MA, Hussein F, Hamdan Z, et al. Ethnopharmacological survey of medicinal plants practiced by traditiona healers and herbalists for treatment of some urological diseases in the West Bank/Palestine. BMC Complement Altern Med. 2017:17:255.

13. Yao GD, Cheng ZY, Shang XY, Gao PY, Huang XX, Song SJ. Coumarins from the bark of Juglans mandshurica exhibited anti-hepatoma inducing apoptosis via activities. Asian Nat Prod Res J. 2017;19:1-9.

14. Joukar S, Ebrahimi S, Khazaei M, Bashiri A, Shakibi MR, Naderi V, et al. Coadministration of walnut (Juglans regia) prevents systemic hypertension induced by long-term use of dexamethasone: a promising strategy for steroid consumers. Pharm Biol. 2017;55:184-9.

15. Fuentealba C, Hernández I, Saa S, Toledo L, Burdiles P, Chirinos R, et al. Colour and in vitro quality attributes of walnuts from different growing conditions correlate with key precursors of primary and secondary metabolism. Food Chem. 2017 Oct;232:664-72.

16. Calcabrini C, De Bellis R, Mancini U, Cucchiarini L, Stocchi V, Potenza L. Protective effect of Juglans regia $L$. walnut extract against oxidative DNA damage. Plant Foods Hum Nutr. 2017;72:192-7.

17. Xu Z, Zhao Y, Ge Y, Peng J, Dong M, Yang G. Characterization of a vacuolar $\mathrm{H}^{+}$-ATPase $\mathrm{G}$ subunit gene from Juglans regia (JVVHAG1) involved in mannitol-induced osmotic stress tolerance. Plant Cell Rep. 2017:36:407-18.

18. Park S, Kim N, Yoo G, Kim SN, Kwon HJ, Jung K, et al. Phenolics and neolignans isolated from the fruits of Juglans mandshurica Maxim and their effects on lipolysis in adipocytes. Phytochemistry. 2017;137:87-93.

19. Mollica A, Zengin G, Locatelli F, Stefanucci A, Macedonio G, Bellagamba G, Onaolapo O, Onaolapo A, Azeez F, Ayileka A, Novellino E. An assessment of the nutraceutical potential of Juglans regia L. leaf powder in diabetic rats. Food Chem Toxicol. 2017;107(PtB):554-64.

20. Singh V, Sherpa M. Neuronal differentiation of murine-like mesenchymal stem cell line: stimulation by Juglans regia L. oil. Appl Biochem Biotechnol. 2017;183:385-95.

21. Pavan V, Ribaudo G, Zorzan M, Redaelli M, Pezzani R, Mucignat-Caretta C, et al. Antiproliferative activity of Juglone derivatives on rat glioma. Nat Prod Res. 2017;31:632-8

22. Salazar R, Pozos ME, Cordero P, Perez J, Salinas MC, Waksman N Determination of the antioxidant activity of plants from Northeast Mexico. Pharm Biol. 2008;46:166-70.

23. Cruz-Vega DE, Verde-Star MJ, Salinas-González N, Rosales-Hernández B, Estrada-García I, Mendez-Aragón P, et al. Antimycobacterial activity of Juglans regia, Juglans mollis, Carya illinoensis and Bocconia frutescens. Phytother Res. 2008;22:557-9.

24. Muñoz-Espinosa LT-GLE, Rivas-Estilla AM, Trujillo-Murillo K, Salazar-Aranda R, De Torres NW, Cordero-Pérez P. Protective effect of four Mexican plants against CCl4-induced damage on the Huh7 human hepatoma cell line. Ann Hepatol. 2011:10:73-9.

25. Verde MJ, García S, Rivas C. Metodología científica para el estudio de plantas medicinales. Rivas-Morales, C., Oranday-Cardenas, MA and VerdeStar MJ (Eds.). Investigación en plantas de importancia médica. Barcelona España Omnia Science, 16: 26-34. DOI. 2016. https://doi.org/10.3926/ oms.313.

26. Zapata-Chavira H, Hernández-Guedea M, Jiménez-Pérez JC, Pérez-Rodríguez E, Muñoz-Espinosa L, Muñoz-Maldonado G, Cordero-Pérez P. Modulation of remote ischemic preconditioning by Proinflammatory cytokines in renal transplant recipients. J Investig Surg. 2017;30:1-9.

27. Draper $\mathrm{HH}$, Hadley M. Malondialdehyde determination as index of lipid peroxidation. Methods Enzymol. 1990;186:421-31.

28. Kobuchi S, Shintani T, Sugiura T, Tanaka R, Suzuki R, Tsutsui H, et al. Renoprotective effects of gamma-aminobutyric acid on ischemia/ reperfusion-induced renal injury in rats. Eur J Pharmacol. 2009;623(1-3): $113-8$.

29. Moosavi SM, Bayat G, Owji SM, Panjehshahin MR. Early renal post-ischaemic tissue damage and dysfunction with contribution of A1-adenosine receptor activation in rat. Nephrology (Carlton) 2009; 14(2):179:88.

30. Mohamadi Yarijani Z, Najafi H, Shackebaeir D, Madani SH, Modarresi M, Jassemi SV. Amelioration of renal and hepatic function, oxidative stress, inflammation and histopathologic damages by Malva sylvestris extract in gentamicin induced renal toxicity. Biomed Pharmacother. 2019;112:108635.

31. Minutoli L, Puzzolo D, Rinaldi M, Irrera N, Marini H, Arcoraci V, et al. ROSmediated NLRP3 inflammasome activation in brain, heart, kidney, and testis ischemia/reperfusion injury. Oxidative Med Cell Longev. 2016;2016:2183026.

32. Limón-Pacheco J, Gonsebatt ME. The role of antioxidants and antioxidantrelated enzymes in protective responses to environmentally induced oxidative stress. Mutat Res. 2009;674:137-47.

33. Kasote DM, Katyare SS, Hegde MV, Bae H. Significance of antioxidant potential of plants and its relevance to therapeutic applications. Int J Biol Sci. 2015;11:982-91.

34. Fukuda T, Ito H, Yoshida T. Antioxidative polyphenols from walnuts (Juglans regia L.). Phytochemistry. 2003;63:795-801.

35. Haque R, Bin-Hafeez B, Parvez S, Pandey S, Sayeed I, Ali M, et al. Aqueous extract of walnut (Juglans regia L.) protects mice against cyclophosphamide-induced biochemical toxicity. Hum Exp Toxicol. 2003;22: 473-80

36. Zhao P, Qi C, Wang G, Dai X, Hou X. Enrichment and purification of total flavonoids from cortex Juglandis Mandshuricae extracts and their suppressive effect on carbon tetrachloride-induced hepatic injury in mice. J Chromatogr B Analyt Technol Biomed Life Sci. 2015;1007:8-17.

37. Hodges DM, DeLong JM, Forney CF, Prange RK. Improving the thiobarbituric acid-reactive-substances assay for estimating lipid peroxidation in plant tissues containing anthocyanin and other interfering compounds. Planta. 1999;207:604-11.

38. Wei H, Chen X, Zong X, Shu H, Gao D, Liu Q. Comparative transcriptome analysis of genes involved in anthocyanin biosynthesis in the red and yellow fruits of sweet cherry (Prunus avium L.). PLoS One. 2015;10(3): e0121164.

39. Landi, M. Commentary to:"Improving the thiobarbituric acid-reactivesubstances assay for estimating lipid peroxidation in plant tissues containing anthocyanin and other interfering compounds" by Hodges et al. Planta (1999) 207: 604-611. 2017 Planta; 245:1067-1067.

40. Hosseinzadeh H, Zarei H, Taghiabadi E. Antinociceptive, anti-inflammatory and acute toxicity effects of juglans regia L. leaves in mice. Iran Red Crescent Med J. 2011;13:27-33.

41. Shen XD, Ke B, Zhai Y, Gao F, Anselmo D, Lassman CR, et al. Stat4 and Stat6 signaling in hepatic ischemia/reperfusion injury in mice: $\mathrm{HO}-1$ dependence of Stat4 disruption-mediated cytoprotection. Hepatology. 2003;37:296-303.

42. Xu H, Manivannan A, Jiang HR, Liversidge J, Sharp PF, Forrester JV, et al. Recruitment of IFN- - -producing (Th1-like) cells into the inflamed retina in vivo is preferentially regulated by P-selectin glycoprotein ligand 1:P/Eselectin interactions. J Immunol. 2004;172:3215-24.

43. Yokota N, Burne-Taney M, Racusen L, Rabb H. Contrasting roles for STAT4 and STAT6 signal transduction pathways in murine renal ischemiareperfusion injury. Am J Physiol Renal Physiol. 2003;285:F319-25.

44. Saat TC, Susa D, Roest HP, Kok NF, van den Engel S, ljzermans JN, et al. A comparison of inflammatory, cytoprotective and injury gene expression profiles in kidneys from brain death and cardiac death donors. Transplantation. 2014;98:15-21.

45. Farmacopea Herbolaria de los Estados Unidos Mexicanos (FHEUM). 2nd ed. Distrito Federal, Mexico: Secretaria de Salud; 2013.

46. Nunez-Melendez E. Plantas Medicinales de Puerto Rico: Folklore y Fundamentos Científicos. San Juan, Puerto Rico: Editorial de la Universidad de Puerto Rico; 1982.

47. Ruijun W, Shi W, Yijun X, Mengwuliji T, Lijuan Z, Yumin W. Antitumor effects and immune regulation activities of a purified polysaccharide extracted from Juglan regia. Int J Biol Macromol. 2015;72:771-5. 
48. Alonso-Castro AJ, Juárez-Vázquez MC, Campos-Xolalpa N. Medicinal plants from Mexico, Central America, and the Caribbean used as Immunostimulants. Evid Based Complement Alternat Med. 2016;2016: 4017676.

49. Peirce A. The American pharmaceutical association practical guide to natural medicines. New York: Morrow; 1999.

50. Qadan F, Thewaini AJ, Ali DA, Afifi R, Elkhawad A, Matalka KZ. The antimicrobial activities of Psidium guajava and Juglans regia leaf extracts to acne-developing organisms. Am J Chin Med. 2005;33(2):197-204.

51. Hajimahmoodi M, Shams-Ardakani M, Saniee P, Siavoshi F, Mehrabani M, Hosseinzadeh $\mathrm{H}$, et al. In vitro antibacterial activity of some Iranian medicinal plant extracts against helicobacter pylori. Nat Prod Res. 2011;25: 1059-66.

52. Hosseini S, Huseini HF, Larijani B, Mohammad K, Najmizadeh A, Nourijelyani $K$, et al. The hypoglycemic effect of Juglans regia leaves aqueous extract in diabetic patients: a first human trial. Daru. 2014;22:19-23.

53. Gushiken LF, Beserra FP, Rozza AL, Bérgamo PL, Bérgamo DA, Pellizzon CH. Chemical and biological aspects of extracts from medicinal plants with antidiabetic effects. Rev Diabet Stud. 2016;13:96-112

54. Orlando RA, Gonzales AM, Hunsaker LA, Franco CR, Royer RE, Vander Jagt $\mathrm{DL}$, et al. Inhibition of nuclear factor kappaB activation and cyclooxygenase2 expression by aqueous extracts of Hispanic medicinal herbs. J Med Food. 2010;13:888-95.

55. Blumenthal M, Goldberg A, Brinckann J. Herbal medicine: expanded commission E monographs. USA: Newton American Botanical Council; 2000. p. 401-3.

56. Jiménez-Gómez Y, López-Miranda J, Blanco-Colio LM, Marín C, PérezMartínez P, Ruano J, et al. Olive oil and walnut breakfasts reduce the postprandial inflammatory response in mononuclear cells compared with a butter breakfast in healthy men. Atherosclerosis. 2009;204:e70-6.

\section{Publisher's Note}

Springer Nature remains neutral with regard to jurisdictional claims in published maps and institutional affiliations.

Ready to submit your research? Choose BMC and benefit from:

- fast, convenient online submission

- thorough peer review by experienced researchers in your field

- rapid publication on acceptance

- support for research data, including large and complex data types

- gold Open Access which fosters wider collaboration and increased citations

- maximum visibility for your research: over $100 \mathrm{M}$ website views per year

At $\mathrm{BMC}$, research is always in progress.

Learn more biomedcentral.com/submissions 